\author{
RAJNHARDT KOKOT \\ ORCID: 0000-0002-6240-7282 \\ Uniwersytet Wrocławski
}

\title{
NIEKTÓRE KONSEKWENCJE I NIEKONSEKWENCJE ZMIAN W ZAKRESIE OCHRONY ŻYCIA I ZDROWIA W NOWELIZACJI KODEKSU KARNEGO Z 13 CZERWCA 2019 ROKU
}

\begin{abstract}
Abstrakt: W artykule podjęto próbę przedstawienia najistotniejszych zmian, jakie nastąpiły w przepisach chroniących życie i zdrowie człowieka wraz z uchwaleniem 13 czerwca 2019 roku nowelizacji kodeksu karnego. Zwraca uwagę ich dwutorowy charakter. $Z$ jednej strony modyfikacje idą w kierunku obostrzenia na poziomie sankcji odpowiedzialności karnej za niektóre przestępstwa stypizowane w rozdziale XIX kodeksu karnego, w tym za cięższe odmiany zabójstwa, spowodowanie uszczerbku na zdrowiu, nieumyślne spowodowanie śmierci czy udział w bójce lub pobiciu. Z drugiej — nowelizacja wprowadza nowe typy przestępstw, nieznane także wcześniejszym kodyfikacjom rodzimego prawa karnego, jak przyjęcie zlecenia zabójstwa czy spowodowanie śmierci więcej niż jednej osoby, a także odmienną od dotychczasowej formułę odpowiedzialności za przygotowanie zabójstwa. Mając na uwadze zakres tych zmian, omawianą nowelizację uznać należy za najgłębiej ingerującą $\mathrm{w}$ stan prawny w zakresie ochrony podstawowych dóbr jednostki pod rządami kodeksu karnego z 1997 roku. Opracowanie zawiera prezentację założeń niektórych spośród przyjętych rozwiązań, analizę zasadności ich wprowadzenia, ocenę ich systemowej spójności, a także analizę następstw, jakie zmiany te mogą pociągać za sobą na płaszczyźnie zwiększenia efektywności zapobiegania i zwalczania przestępczości skierowanej przeciwko życiu i zdrowiu człowieka.
\end{abstract}

Słowa kluczowe: nowelizacja, życie, zdrowie, nieumyślne spowodowanie śmierci, bójka, pobicie, punitywność, penalizacja, kryminalizacja, racjonalność, represyjność

\section{UWAGI WPROWADZAJĄCE}

Nowelizacja kodeksu karnego z 13 czerwca 2019 roku już od chwili, gdy jej założenia, treść i uzasadnienie ujrzały światło dzienne w prezentowanych kolejnych wersjach projektowanych zmian, w środowisku karnistycznym — zarówno nauki prawa karnego, jak i praktyki wymiaru sprawiedliwości - wzbudzała szczególne emocje. Nie były to przy tym emocje o mieszanym charakterze, a w każdym razie emocje „zmieszane” proporcjonalnie. W opiniach dotyczących 
omawianej reformy przeważał wyraźny ton krytycyzmu. Dezaprobatę, a nierzadko kategoryczny sprzeciw wobec nowelizacji oparto na argumentach natury kryminologicznej, systemowej oraz statystycznej. W piśmiennictwie zwrócono uwagę na nieracjonalność i niekonsekwencję przyjętych rozwiązań prawnych oraz brak kryminalnopolitycznego uzasadnienia ich wprowadzenia ${ }^{1}$.

Celem i zadaniem niniejszego opracowania jest prezentacja i ocena niektórych zmian wprowadzonych mocą tej nowelizacji w rozdziale XIX kodeksu karnego, zarówno o charakterze „ilościowym”, przejawiających się w szczególności W zwiększonej surowości odpowiedzialności karnej za przestępstwa przeciwko życiu i zdrowiu, jak i ,jakościowym”, których wyrazem jest obecność w ustawie nowych rozwiązań i konstrukcji normatywnych w zakresie prawnej ochrony tych dóbr. Podstawowym pytaniem, na które w kontekście wprowadzonych zmian należy odpowiedzieć, jest pytanie o ich ratio legis. Może bowiem powstać wątpliwość a w obliczu przywołanych obiekcji, licznie formułowanych w środowisku nauki prawa karnego i praktyki wymiaru sprawiedliwości, wątpliwość taka musi powstać — czy zmiany wprowadzone mocą nowelizacji kodeksu karnego z 13 czerwca 2019

${ }^{1}$ Por. A. Barczak-Oplustil et al., Opinia do uchwały Senatu Rzeczypospolitej Polskiej z dnia 24 maja 2019 roku w sprawie ustawy o zmianie ustawy - Kodeks karny oraz niektórych innych ustaw, uchwalonej przez Sejm Rzeczypospolitej Polskiej na 81. posiedzeniu w dniu 16 maja 2019 roku, Kraków, dnia 9 czerwca 2019 roku, https://www.rpo.gov.pl/sites/default/files/ Opinia\%20Krakowskiego\%20Instytutu\%20Prawa\%20Karnego\%20Fundacja\%20ws.\%20poprawek\%20Senatu\%209\%20czerwca\%202019.pdf (dostęp: 20.07.2019); A. Sakowicz, Stanowisko dla Rzecznika Praw Obywatelskich w związku z uchwalaniem przez Sejm RP ustawy z dnia 16 maja 2019 roku o zmianie ustawy - Kodeks karny oraz niektórych innych ustaw, Białystok, 21 maja 2019 roku, https://www.rpo.gov.pl/sites/default/files/Opinia\%20dr.\%20hab.\%20Andrzeja\%20 Sakowicza\%20ws\%20zmian\%20w\%20prawie\%20karnym\%2C\%2021\%20maja\%202019.pdf (dostęp: 20.07.2019); J. Giezek et al., Opinia na temat projektu zmian przepisów kodeksu karnego (uchwała Senatu Rzeczypospolitej Polskiej z dnia 24 maja 2019 roku), Wrocław 2019, https:// www.rpo.gov.pl/sites/default/files/Opinia Katedry Prawa Karnego Materialnego WPAE UWr do nowelizacji kodeksu karnego.pdf (dostęp: 20.07.2019); Opinia Rzecznika Praw Obywatelskich do ustawy z dnia 16 maja 2019 roku o zmianie ustawy — Kodeks karny oraz niektórych innych ustaw, Warszawa, 20 maja 2019 roku, https://www.rpo.gov.pl/sites/default/files/Opinia\%20RPO\%20 dla\%20Senatu\%20ws\%20zmian\%20w\%20prawie\%20karnym\%2C\%2020\%20maja\%202019. pdf (dostęp: 20.07.2019); T. Gardocka, Opinia dotycząca ustawy zmieniającej kodeks karny i niektóre inne ustawy, uchwalonej przez Sejm dnia 16 maja 2019 roku i skierowanej do Senatu, sporządzona dnia 22 maja 2019 roku na prośbę Rzecznika Praw Obywatelskich, https://www.rpo. gov.pl/sites/default/files/Opinia\%20dr\%20hab.\%20Teresy\%20Gardockiej\%20ws\%20zmian\%20 w\%20prawie\%20karnym\%2C\%2022\%20maja\%202019.pdf (dostęp: 20.07.2019); Sąd Najwyższy Rzeczypospolitej Polskiej, Biuro Studiów i Analiz, Opinia do projektu ustawy o zmianie ustawy - Kodeks karny oraz niektórych innych ustaw, Warszawa, 26 kwietnia 2019, https://www.rpo. gov.pl/sites/default/files/Uwagi\%20S\%C4\%85du\%20Najwy\%C5\%BCszego $\% 20 \mathrm{do} \% 20$ projektu\%20zmian\%20prawa\%20karnego\%2026\%20kwietnia\%202019.pdf (dostęp: 20.07.2019); Opinia o nowelizacji KK 158 prawników ze wszystkich ośrodków naukowych, 23 czerwca 2019 roku, https://www.rpo.gov.pl/sites/default/files/Opinia $\% 20 \% 200 \% 20$ nowelizacji\%20Kk\%20158\%20 prawnik\%C3\%B3w\%20ze \%20\%20wszystkich\%20\%20o\%C5\%9Brodk\%C3\%B3w\%20naukowych\%2C\%2023\%20czerwca\%202019.pdf (dostęp: 20.07.2019). 
roku — w każdym razie znaczna ich część — są zmianami racjonalnymi, a więc uzasadnionymi i celowymi. Ustalenie rozsądnej przyczyny i doniosłego celu decyduje wszakże o sensowności wszelkich poczynań reformatorskich i wszelkich przeobrażeń, także tych na niwie normatywnej. W tym stanie rzeczy postawić należy pytanie, czy modyfikacja regulacji ustawowych w zakresie rozdziału XIX kodeksu karnego z 1997 roku, w skali i treści przyjętej w nowelizacji, była działaniem koniecznym, wymaganym i oczekiwanym, rzeczywiście służącym poprawie jakości ochrony dóbr, jakimi są życie i zdrowie człowieka — słowem, czy była właściwym krokiem w kierunku jej wzmocnienia i zwiększenia efektywności. Odpowiedzi wymagają także pytania o konstrukcyjną i aksjologiczną „poprawność” nowych form prawnych. Rodzi się wątpliwość, czy i w jakim stopniu wpisują się one w dotąd istniejący system reakcji prawa karnego na przestępczość przeciwko życiu i zdrowiu, w tym, czy konstrukcje te są spójne z rozwiązaniami dotychczasowymi, obecnymi w obowiązującym stanie prawnym. W obliczu wyrażanych w piśmiennictwie uwag powstaje bowiem wrażenie, któremu trudno się oprzeć, że większość wprowadzonych zmian nie jest ani potrzebna, ani konsekwentna, ani nawet logiczna.

\section{KIERUNKI I CHARAKTER ZMIAN - OGÓLNA CHARAKTERYSTYKA}

Podkreślenia wymaga radykalizm i zakres działań nowelizacyjnych. Swym zasięgiem - mimo iż uzasadnienie projektu dość wąsko określiło charakter i kierunki zaproponowanych zmian - objęły one bardzo liczną grupę unormowań prawnych — zarówno w części ogólnej, jak i szczególnej ustawy karnej. W tym szeregu znalazły się także przepisy określające „standardy” prawa karnego, jego fundamentalne konstrukcje prawne, „uświęcone” długoletnią tradycją stosowania, sprawdzone w praktyce orzeczniczej i utrwalone w świadomości środowiskowej w ciągu wielu dekad, korzeniami sięgające nie tylko początków obowiązywania kodeksu karnego z 1997 roku, ale nierzadko też rozwiązań prawnych „debiutujących" w rodzimym prawie karnym już w kodeksie J. Makarewicza.

Fundamentalnym założeniem nowelizacji kodeksu karnego z 13 czerwca 2019 roku było - wprost deklarowane w jego uzasadnieniu — obostrzenie odpowiedzialności karnej. Jak argumentują autorzy wprowadzonych zmian, „obecny stan prawny nie odpowiada postulatom wynikającym z funkcji ochronnej prawa karnego, przez co nie zapewnia wystarczających narzędzi dla ograniczenia przestępczości i zabezpieczenia istotnych wartości społecznych"2. Uzasadnienie określiło jednocześnie środki służące realizacji tego kierunku: „Dla realizacji tych celów niezbędne jest odpowiednie ukształtowanie rodzaju i wysokości sankcji karnej grożącej za dany

2 Uzasadnienie projektu nowelizacji kodeksu karnego - wersja z 5 kwietnia 2019 roku, s. 1, https://legislacja.rcl.gov.pl (dostęp: 20.07.2019). 
typ przestępstwa, uwzględniające potrzebę surowej represji wobec sprawców tych czynów, które budzą silną społeczną potrzebę odpłaty i napiętnowania"3.

Przyjęty kierunek zwiększenia punitywności rozwiązań prawnych miał być realizowany zarówno na płaszczyźnie części ogólnej, jak i szczególnej. Z jednej strony, w części ogólnej, wyrazem poprawy skuteczności prawa karnego wynikającej z jego większej surowości było między innymi rozszerzenie zakresu stosowania instytucji nadzwyczajnego obostrzenia kary, modyfikacja granic kary pozbawienia wolności, przemodelowanie stosowania dożywotniego pozbawienia wolności czy też zmiany dotyczące ogólnych dyrektyw sądowego wymiaru kary ukierunkowane „w stronę wyboru bardziej surowej sankcji”"4 $Z$ drugiej strony, w części szczególnej, realizowane założenie znajdowało swój wyraz w zwiększonej surowości sankcji przewidzianych za określone - a trzeba dodać, liczne - typy przestępstw. Ponadto nowelizacja miała też ogólniejsze zadanie, co można odebrać jako rodzaj jej „,wartości dodanej”, w postaci usunięcia lub zmiany dotychczasowych nieracjonalnych i nieefektywnych unormowań, dotkniętych ,wadami merytorycznymi”, a także „wyeliminowanie niespójności i luk prawnych", które ujawniły się w toku stosowania obowiązującego stanu prawnego ${ }^{5}$. Zwiększenie represyjności odpowiedzialności za poszczególne przestępstwa realizowane miało być — w myśl dyrektyw wyrażonych w uzasadnieniu — „w sposób selektywny i racjonalny, oparty na wnikliwej ocenie zasadności wzmocnienia prawnokarnej ochrony w określonych dziedzinach życia społecznego, w które prawo karne wkracza, stawiając tam ludzkim zachowaniom nieprzekraczalne granice" ". Wśród wspomnianych w uzasadnieniu „dziedzin” naruszeń dóbr prawnych wymagających korektury reakcji karnej w kierunku jej obostrzenia znalazła się sfera ochrony życia i zdrowia.

\section{KIERUNKI I CHARAKTER ZMIAN - PRZESTĘPSTWA PRZECIWKO ŻYCIU I ZDROWIU}

Zmiany w regulacji rozdziału XIX kodeksu karnego zmierzają w dwóch kierunkach ${ }^{7}$. Wyrazem pierwszego z nich — który na potrzeby niniejszego opracowania można określić mianem „ilościowego” — jest znaczne obostrzenie granic za

3 Ibidem.

4 Ibidem, s. 2.

5 Ibidem.

${ }^{6}$ Ibidem, s. 20. Obok objętych zmianami „dziedzin” wprost wymienionych w uzasadnieniu — ochrona życia i zdrowia, wolności seksualnej oraz własności — znalazły się jednak także liczne obszary dotyczące ochrony innych dóbr prawnych. Modyfikacja dotyczy również między innymi przepisów regulujących prawidłowość działania instytucji państwowych i samorządowych, rzetelność obrotu gospodarczego, bezpieczeństwo w komunikacji czy porządek publiczny.

${ }^{7}$ Należy dodać, że zmiany w zakresie ochrony życia i zdrowia znalazły się także poza rozdziałem XIX kodeksu karnego. Ich wyrazem mogą być między innymi liczne modyfikacje granic odpowiedzialności za przestępstwa, których skutkiem jest śmierć lub uszczerbek na zdrowiu człowieka, 
niektóre, w tym najcięższe, przestępstwa stypizowane w tym rozdziale. Obejmują one zarówno dolne, jak i górne progi sankcji. Nie powinno budzić wątpliwości, że zwłaszcza te modyfikacje, które dotyczą dolnych progów zagrożenia, jako tych, które w ramach zwyczajnego wymiaru kary kształtują obligatoryjne minimum odpowiedzialności karnej, istotnie wpływają na praktykę wymiaru sprawiedliwości i ogólny obraz punitywności sankcji karnych.

Wśród zmian, jakie na tej płaszczyźnie nastąpiły, wskazać należy zwłaszcza podwyższenie granic odpowiedzialności za zabójstwo w typie podstawowym oraz kwalifikowanym. W pierwszym z nich dolna granica zagrożenia podniesiona została z „tradycyjnie” wytyczanego od bez mała półwiecza poziomu 8 lat pozbawienia wolności, przyjętego za to przestępstwo już w kodeksie karnym z 1969 roku, do lat 10. Modyfikacja w zakresie ogólnych unormowań dotyczących terminowej kary pozbawienia wolności górny próg zagrożenia za tę zbrodnię przesunęła na poziom lat 30. Zauważalną zmianą w sankcji za zabójstwo jest także brak kary punktowej 25 lat pozbawienia wolności, co jest konsekwencją jej usunięcia mocą omawianej nowelizacji z ogólnego katalogu kar przewidzianych w kodeksie. Ustawodawca zrezygnował $\mathrm{z}$ tej obecnej w systemie polskiego prawa karnego od pięciu dekad kary jako niedającej „możliwości miarkowania kwantum prawnokarnej dolegliwości”, „płynnej” reakcji na konkretne przestępstwo, co w wielu wypadkach w praktyce może prowadzić do wymiaru „kary nieadekwatnej, tj. zbyt łagodnej lub zbyt surowej”, co w konsekwencji sprzeczne jest z zasadą indywidualizacji odpowiedzialności karnej ${ }^{8}$. Niezmiennie najsurowszą karą przewidzianą za zabójstwo w typie podstawowym pozostaje kara dożywotniego pozbawienia wolności, choć nie można nie wspomnieć, że bezwzględny charakter tej kary przewidziany w wypadkach określonych w ustawie istotnie zmienia jakość jej dolegliwości. Za zabójstwo w typie kwalifikowanym nowelizacja podniosła dolny próg zagrożenia do 15 lat pozbawienia wolności w miejsce dotychczasowych 12 lat. Zbrodnia ta — tak jak przed zmianą — jest jednocześnie zagrożona bezterminową karą pozbawienia wolności. Modyfikacja granic zagrożenia objęła także sankcję art. $154 \S 2$ k.k. Górna granica odpowiedzialności karnej przewidziana za przestępstwo przerwania ciąży kwalifikowane przez skutek w postaci śmierci kobiety ciężarnej, wynosząca przed nowelizacją 12 lat pozbawienia wolności, podniesiona została do poziomu lat 15 . Uwagę zwraca radykalna zmiana zagrożenia karą za nieumyślne spowodowanie śmierci. Dotychczasowa sankcja obejmująca karę pozbawienia wolności od 3 miesięcy do 5 lat zastąpiona została progami zagrożenia od roku do 10 lat pozbawienia wolności. Oznacza to, że na dolnym poziomie zagrożenia wzrosła ona czterokrotnie, natomiast na poziomie górnym — dwukrotnie. To jedna z najradykalniejszych modyfikacji karalności w ujęciu omawianej

a także wprowadzenie nowego kwalifikowanego typu przestępstwa groźby karalnej, gdy sprawca „grozi popełnieniem przestępstwa zabójstwa lub uszkodzenia ciała” (art. 190 § 1a k.k.).

8 Uzasadnienie projektu nowelizacji kodeksu karnego..., s. 2. 
nowelizacji ${ }^{9}$. Dalsze zmiany w obrębie tego przestępstwa dotyczą nowego zakresu typizacji nieumyślnych zachowań powodujących śmierć człowieka, o czym szerzej w dalszej części opracowania.

Nowelizacja zmieniła także prawnokarną ocenę najcięższych zamachów przeciwko zdrowiu człowieka. Typ podstawowy przestępstwa spowodowania ciężkiego uszczerbku na zdrowiu (art. $156 \S 1$ k.k.), dotąd zagrożony karą od 3 lat pozbawienia wolności do lat 15 , w znowelizowanym stanie prawnym zagrożony jest sankcją od 3 do 20 lat. Ostatnia zmiana w zakresie zagrożeń karą za przestępstwa stypizowane w rozdziale XIX kodeksu dotyczy udziału w bójce lub pobiciu. Jak wynika z art. 158 k.k. w jego ponowelizacyjnym kształcie, typ podstawowy z $§ 1$ zagrożony jest karą od 3 miesięcy do 5 lat pozbawienia wolności w miejsce dotychczasowego zagrożenia do lat 3; typ kwalifikowany ze względu na nieumyślny skutek w postaci ciężkiego uszczerbku na zdrowiu przewiduje sankcję od roku do lat 10 kary pozbawienia wolności, która zastąpiła przedział zagrożenia od 6 miesięcy do 8 lat; wreszcie kwalifikowana odmiana tego przestępstwa, związana z wystąpieniem skutku śmiertelnego, w miejsce dotychczasowych progów zagrożenia od roku do lat 10 zagrożona jest karą od lat 2 do 15 . Dalej idące zmiany w katalogu następstw popełnienia tego przestępstwa staną się przedmiotem odrębnych uwag w końcowej części niniejszych rozważań.

W kontekście modyfikacji odpowiedzialności karnej przewidzianej za odmiany przestępstw stypizowanych $\mathrm{w}$ art. 158 § 1-3 k.k. zwracać może uwagę niekonsekwencja ustawodawcy, zorientowanego - jak wielokrotnie podkreśla uzasadnienie - na wzmożenie ochrony życia i zdrowia człowieka przed gwałtownymi zamachami. Bez zmian pozostały bowiem granice odpowiedzialności karnej grożącej za typ kwalifikowany udziału w bójce lub pobiciu ze względu na użyte w trakcie tych zdarzeń niebezpieczne przedmioty (art. 159 k.k.). Przestępstwo określone w tym przepisie niezmiennie zagrożone jest karą od 6 miesięcy do 8 lat pozbawienia wolności. Znacząco zmieniła się więc dotychczasowa relacja między oceną niebezpiecznych dla życia lub zdrowia zachowań w postaci udziału w bójce lub pobiciu bez użycia oraz z użyciem „niebezpiecznego przedmiotu”. Ujmując rzecz w pewnym uproszczeniu, można uznać, że autorzy nowelizacji wzmocnili ochronę życia i zdrowia przed nieumyślnym ich naruszeniem w trakcie umyślnie wywołanych zdarzeń objętych regulacją art. 158-159 k.k., proporcjonalnie osłabili natomiast wytworzenie zwiększonego narażenia tych dóbr w związku z użyciem przez ich uczestników broni palnej, noża lub innych podobnie niebezpiecznych „akcesoriów”. Intensywniejsza ochrona tych dóbr przed nieumyślnymi zamachami pozostaje w ścisłej relacji z oceną nieumyślnych zamachów na życie człowieka wynikającą z sankcji art. 155 k.k. Należy jednak zwrócić uwagę, że zmiana idąca

${ }^{9}$ Na pierwszy plan, jako norma ogólna, zdaje się w tym zestawieniu wysuwać represyjna reguła nadzwyczajnego obostrzenia w przypadku przestępstwa ciągłego, pozwalająca — zgodnie $\mathrm{z}$ art. 57b k.k. — na wymierzenie kary do górnego zagrożenia zwiększonego dwukrotnie. 
w tym kierunku nie ma charakteru systemowego, nie obejmuje bowiem wszelkich zamachów stypizowanych w kodeksie karnym, których obocznym, nieumyślnym skutkiem jest śmierć lub ciężki uszczerbek na zdrowiu człowieka.

\section{TYP KWALIFIKOWANY NIEUMYŚLNEGO SPOWODOWANIA ŚMIERCI - ART. 155 § 2 K.K.}

Więcej uwagi należy poświęcić zmianom, które z perspektywy prowadzonej analizy można zaliczyć do zmian o charakterze ,jakościowym”. Ten kierunek nowelizacji łączy się z wprowadzeniem nowych rozwiązań prawnych, niewystępujących dotąd w rozdziale dotyczącym przestępstw chroniących życie i zdrowie, bądź nawet takich konstrukcji, które dotąd w ogóle nie były uregulowane w systemie polskiego prawa karnego. Pośród tych modyfikacji szczególne miejsce zajmuje określenie $\mathrm{w}$ ustawie karnej nowego typu czynu zabronionego, jakim jest odpłatne przyjęcie zlecenia zabójstwa przewidziane w art. 148a $\S 1$ k.k., oraz typizacja odmiany kwalifikowanej nieumyślnego spowodowania śmierci z art. 155 $\S 2$ k.k. W tej grupie zmian mieści się też wprowadzona do ustawy karnej reguła karalności przygotowania zabójstwa (art. 148 § 5 k.k.) oraz nowa jakość sankcji przewidzianej w art. $158 \S 4$ k.k. W niniejszym opracowaniu analizie poddane zostały zmiany, które objęły konstrukcję przestępstwa nieumyślnego spowodowania śmierci, a także nowe ujęcie reakcji karnej na przestępstwo udziału w pobiciu ${ }^{10}$.

Poza zmianą sankcji przewidzianej za nieumyślne spowodowanie śmierci obejmującej ustawowe zagrożenie karą pozbawienia wolności od 3 miesięcy do 5 lat — które, jak podkreślono z dezaprobatą w uzasadnieniu projektu, było identyczne z sankcją przewidzianą między innymi za podstawowy typ kradzieży, czego nie można było zaakceptować ze względu na „hierarchię wartości” naruszanych w obu przypadkach dóbr prawnych ${ }^{11}$ — nowelizacja kodeksu karnego z 13 czerwca 2019 roku wprowadziła typ kwalifikowany tego przestępstwa. Dotychczasowy przepis określający jedyną, autonomiczną i „ogólną” postać nieumyślnego spowodowania śmierci człowieka (art. 155 k.k.) — abstrahując od licznych wypadków wyodrębnionych w ustawie karnej, w których tak określony skutek stanowi znamię kwalifikujące przez następstwa inne typy czynów zabronionych

10 Uwagi dotyczące nowych rozwiązań prawnych w zakresie umyślnych zamachów na życie — przestępstwo odpłatnego przyjęcia zlecenia zabójstwa (art. 148a $§ 1$ k.k.) oraz penalizacja przygotowania zabójstwa (art. $148 \S 5$ k.k.) — tworzą treść odrębnych opracowań poświęconych tym regulacjom. Zob. R. Kokot, Penalizacja przygotowania zabójstwa w nowelizacji kodeksu karnego z 13 czerwca 2019 roku, „Przegląd Prawa i Administracji” 120, 2020; oraz idem, Przestępstwo przyjęcia zlecenia zabójstwa (art. 148 a 1 k.k.) w ujęciu nowelizacji kodeksu karnego z 13 czerwca 2019 roku, „Przegląd Prawa i Administracji” 122, 2020.

11 Uzasadnienie projektu nowelizacji kodeksu karnego..., s. 26. 
— stał się typem podstawowym (art. $155 \S 1$ k.k.), obok którego wyodrębniona została jego cięższa odmiana ,ze względu na rozległość przestępnego skutku”12.

Jak stanowi art. $155 \S 2$ k.k., odpowiedzialności w nim przewidzianej podlega ten, kto „powoduje śmierć więcej niż jednej osoby”. Tym samym ustawodawca odwołał się do analogicznej — choć z racji odmiennej treści strony podmiotowej, nie takiej samej - motywacji, jaka determinowała kreatywne działania twórców ustawy karnej wprowadzających ponad dwadzieścia lat temu do rodzimej kodyfikacji - mimo wyraźnego sprzeciwu lub chłodnego dystansu części przedstawicieli środowiska karnistycznego ${ }^{13}$ — kwalifikowany typ zabójstwa wyodrębniony między innymi na podstawie skądinąd poprawnego w sensie logicznym założenia, że nie tym samym jest jednoczynowe zabójstwo jednego człowieka i takież zabójstwo dwóch lub większej liczby osób. Jak wynika z uzasadnienia projektu, przyjęte w kodeksie zmiany w zakresie penalizacji i zmodyfikowanej typizacji nieumyślnego spowodowania śmierci więcej niż jednej osoby zorientowane są na „ogólnoprewencyjny efekt”, którego nie można osiągnąć jedynie $\mathrm{w}$ ramach podstawowego typu tego przestępstwa ${ }^{14}$. Dotychczasowy stan prawny — jak konstatują twórcy tego rozwiązania — zwłaszcza zaś sankcja przewidziana za nieumyślne spowodowanie śmierci „nie przystaje do abstrakcyjnego stopnia społecznej szkodliwości tego typu czynu i nie spełnia należycie swych funkcji prewencyjnych"15.

Warunkiem pociągnięcia do odpowiedzialności z art. $155 \S 2$ k.k. jest przypisanie nieumyślnego spowodowania śmierci więcej niż jednej osoby, a więc co najmniej dwóch osób. Wystąpienie większej liczby ofiar zachowania nieumyślnego może być wzięte pod uwage jedynie w ramach sądowego wymiaru kary za to przestępstwo przy uwzględnieniu okoliczności wskazanej w art. $53 \S 2$ k.k., jaką

12 Ibidem, s. 25-26.

13 Por. A. Zoll, [w:] Kodeks karny. Część szczególna. Komentarz, t. 2, red. A. Zoll, Kraków 2006, s. 235; T. Bojarski, Kwalifikowane i uprzywilejowane typy przestęstw w nowym kodeksie karnym, [w:] U progu nowych kodyfikacji karnych. Ksiega pamiatkowa ofiarowana Prof. Leonowi Tyszkiewiczowi, red. O. Górniok, Katowice 1999, s. 39.

14 Wypada w tym miejscu ad verbum przytoczyć argumentację tego rozwiązania rozwiniętą w uzasadnieniu projektu. Jak wynika z fragmentu odnoszącego się do potrzeby zintensyfikowania ochrony życia przed zamachami nieumyślnymi, ,przy ocenie stopnia szkodliwości społecznej przestępstwa nieumyślnego spowodowania śmierci człowieka nie można przejść do porządku nad znaczną różnicą w zakresie stopnia społecznej szkodliwości tego przestępstwa w wypadku, gdy jego skutkiem jest śmierć jednej lub większej liczby osób. Te różnice powinny manifestować się również przyjęciem w tym drugim wypadku surowszych granic odpowiedzialności karnej sprawcy. W świadomości społecznej powinno istnieć ugruntowane przekonanie, które należy wyrabiać także odpowiednim ukształtowaniem sankcji [...], że niezachowanie przez człowieka przeciętnego obowiązku ostrożności w sytuacji, w której na podstawie normalnej zdolności przewidywania i obowiązku dbałości o życie ludzkie można wymagać od niego, aby nie dopuścił się nastąpienia skutku w postaci śmierci człowieka, powinno i będzie skutkować wobec niego sankcją karną tym surowszą, im rozleglejszy charakter będą miały te skutki" - uzasadnienie projektu nowelizacji kodeksu karnego..., s. 25-26.

15 Ibidem, s. 26. 
jest „rozmiar ujemnych następstw przestępstwa”. Ich „rodzaj” i rozmiar w wymiarze minimalnym - co najmniej dwie ofiary — determinuje bowiem rodzaj kary oraz wysokość dolnej i górnej granicy sankcji, a więc odpowiedzialność na płaszczyźnie ustawowego wymiaru kary. Bez znaczenia dla odpowiedzialności za przestępstwo określone w art. $155 \S 2$ k.k. jest to, czy śmierć ofiar nastąpiła jednocześnie, czy w różnym czasie, w tym samym miejscu czy w kilku. O jedności czynu decyduje wyłącznie chwila i miejsce zachowania sprawcy, nie zaś chwila wystąpienia jego skutków czy miejsce ich wystąpienia. Analogicznie jak w wypadku typu podstawowego z art. $155 \S 1 \mathrm{k} . \mathrm{k}$. i przy spełnieniu takich samych warunków znamiona kwalifikowanego nieumyślnego spowodowania śmierci można zrealizować zarówno w formie działania, jak i zaniechania. Warunkiem odpowiedzialności karnej za zaniechanie, w myśl art. 2 k.k., jest istnienie po stronie sprawcy prawnego, szczególnego obowiązku zapobiegnięcia skutkowi. W takim zakresie jest to zatem przestępstwo indywidualne niewłaściwe.

Znamion przestępstwa $\mathrm{z}$ art. 155 § $2 \mathrm{k} . \mathrm{k}$. z powodów analogicznych jak w wypadku umyślnego jednoczynowego zamachu na życie więcej niż jednej osoby nie zrealizuje nieumyślne spowodowanie śmierci kobiety w ciąży. Każda z ofiar nieumyślnego spowodowania śmierci „więcej niż jednej osoby” z art. $155 \S 2$ k.k. musi spełniać warunek stawiany przedmiotowi czynności wykonawczej nieumyślnego spowodowania śmierci w typie podstawowym, a więc być „człowiekiem" w rozumieniu znamion art. $155 \S 1$ k.k. ${ }^{16}$ Ocena w tym zakresie — w myśl przyjętych ustaleń wykładni sądowej i doktrynalnej — zmieni się z chwilą rozpoczęcia akcji porodowej lub podjęcia działań zmierzających do przeprowadzenia zabiegu cesarskiego cięcia ${ }^{17}$. Naruszenie reguł ostrożności prowadzące do śmierci kobiety będącej w trakcie porodu oraz rodzącego się dziecka zrealizuje więc znamiona typu kwalifikowanego określonego w art. 155 § 2 k.k.

Większych wątpliwości nie wywołuje strona podmiotowa tego przestępstwa. Sprawca nie może chcieć ani nawet godzić się na śmierć co najmniej dwóch osób. Wielość skutków wynikających z jednego zachowania nieumyślnego może być objęta różnymi formami nieumyślności w rozumieniu art. $9 \S 2$ k.k. Nieumyślny skutek w postaci śmierci jednej osoby może zatem wynikać ze świadomej nieumyślności, podczas gdy śmierć innej będzie skutkiem nieumyślności nieświadomej. W wypadku gdy sprawca swoim zamiarem, dopuszczając się jednego czynu, obejmował śmierć tylko jednej osoby, a skutek w postaci śmierci co najmniej dwóch innych osób był objęty nieumyślnością, świadomą lub nieświadomą, za-

16 A. Zoll, op. cit., s. 261; V. Konarska-Wrzosek, [w:] Kodeks karny. Komentarz, red. V. Konarska-Wrzosek, Warszawa 2016, s. 725; R. Kokot, [w:] Kodeks karny. Komentarz, red. R.A. Stefański, Warszawa 2018, s. 917; odmiennie K. Daszkiewicz, Przestępstwa przeciwko życiu i zdrowiu. Rozdzial XIX Kodeksu karnego. Komentarz, Warszawa 2000, s. 82.

17 Uchwała SN z 26 października 2006 roku, sygn. I KZP 18/06, OSNKW 2006, nr 11, poz. 97; postanowienie SN z 30 października 2008 roku, sygn. I KZP 13/08, OSNKW 2008, nr 11, poz. 90; wyrok SN z 27 września 2010 roku, sygn. V KK 34/10, OSNKW 2010, nr 12, poz. 105; K. Wiak, [w:] Kodeks karny. Komentarz, red. A. Grześkowiak, K. Wiak, Warszawa 2018, s. 847. 
stosowanie znajdzie konstrukcja kumulatywnego zbiegu przepisów ustawy obejmującego art. 148 § 1 k.k., względnie któryś z przepisów typizujących zabójstwo kwalifikowane $\mathrm{z}$ art. 148 § 2 lub 3 k.k. oraz art. 155 § 2 k.k.

W zastępstwie twórców omawianego przepisu, którzy w uzasadnieniu podali jedynie ogólne motywy wprowadzenia omawianej zmiany, wypada nieco szerzej i precyzyjniej objaśnić ratio legis regulacji art. 155 § 2 k.k. Typizację nieumyślnego spowodowania jednym czynem śmierci więcej niż jednej osoby należy uznać niewątpliwie - jak wcześniej wspomniano - za przejaw tej samej tendencji ustawodawcy, która znalazła wyraz w wyizolowaniu z zakresu podstawowego typu zabójstwa w rozumieniu art. $148 \S 1$ k.k. jego cięższej odmiany, gdy sprawca jednym czynem zabija więcej niż jedną osobę (art. $148 \S 3$ in principio k.k.). Zmiana ta idzie więc w kierunku normowania przypadków realizacji „tym samym czynem" wielości skutków objętych regulacją tego samego przepisu, który to przypadek wymyka się regułom konstrukcji kumulatywnego zbiegu przepisów ustawy, wymagającego multiplikacji skutków objętych znamionami określonymi „W dwóch albo więcej przepisach ustawy” (art. 11 § 2 k.k.). Nie ulega wątpliwości, że wielość tożsamych skutków tego samego zachowania, niezależnie od tego, czy są to skutki umyślne, czy nieumyślne, istotnie wpływa na ocenę stopnia społecznej szkodliwości na płaszczyźnie przedmiotowej — a w przypadku zachowań umyślnych dodatkowo też na płaszczyźnie strony podmiotowej — i jako taka okoliczność powinna znaleźć odzwierciedlenie nie tylko w ramach sądowego, lecz także ustawowego wymiaru kary. Rzecz w tym, że przyjęte w nowelizacji kodeksu karnego rozwiązanie wciąż nie jest rozwiązaniem kompleksowym, a jedynie kolejnym unormowaniem fragmentarycznym. Trudno bowiem przyjąć konsekwencję ustawodawcy, skoro niezmiennie poza zakresem typizacji czynów zabronionych pozostaje, przykładowo, umyślne bądź nieumyślne spowodowanie jednym czynem ciężkiego uszczerbku na zdrowiu więcej niż jednej osoby, choć $\mathrm{z}$ analogicznych powodów, jak jednoczynowe zabójstwo lub jednoczynowe nieumyślne spowodowanie śmierci więcej niż jednej osoby, zasługiwałyby one na surowsze potraktowanie ze względu na multiplikację tożsamych skutków. W tym kontekście należy podkreślić, że lepszym rozwiązaniem byłaby zmiana o generalnym charakterze, polegająca na modyfikacji dotychczasowej formuły kumulatywnego zbiegu przepisów tak, by swym zakresem obejmował także przypadki jednoczynowego zwielokrotnienia skutków tego samego rodzaju, określonych w tym samym przepisie ustawy. Jako możliwą konsekwencję takiego unormowania na etapie wymiaru kary — zresztą nie tylko w odniesieniu do wielości skutków jednorodnych, będących efektem tego samego czynu — można by przewidzieć możliwość nadzwyczajnego obostrzenia kary. Nie można w tym kontekście tracić z pola widzenia tego, że próba szerszego rozwinięcia w części szczególnej przyjętego w nowelizacji modelu typizacji odmian kwalifikowanych przez wielość tożsamych skutków mogłaby doprowadzić do znacznego, nieakceptowalnego wzrostu wskaźnika kazuistyki unormowań tej części ustawy karnej. 
Podstawą wyodrębnienia kwalifikowanego typu nieumyślnego spowodowania śmierci jest kryterium rozmiaru następstw nieostrożnego zachowania sprawcy. Nie powinno budzić wątpliwości, choć z konstrukcji dyspozycji przepisu art. 155 $\S 2$ k.k. nie wynika to expressis verbis — odmiennie niż w przypadku typu kwalifikowanego zabójstwa określonego $\mathrm{w}$ art. 148 § 3 in principio k.k. — iż w przepisie tym chodzi wyłącznie o jednoczynowe („tym samym czynem”), nieumyślne zwielokrotnienie skutku śmiertelnego ${ }^{18}$. W przeciwnym razie przepis ten miałby zastosowanie także do stanów faktycznych uregulowanych w kodeksie karnym jako ciąg, względnie realny zbieg przestępstw nieumyślnego spowodowania śmierci, stanowiąc unormowanie „konkurencyjne” wobec regulacji art. 85 k.k. i art. 91 k.k. ${ }^{19}$ Przepis ten nie może być również traktowany jako regulacja zachowań wieloczynnościowych, nieumyślne spowodowanie śmierci nie jest bowiem przestępstwem złożonym. Z tej perspektywy omawiana regulacja uzasadnia zarzut kolejnej legislacyjnej nieścisłości. Wydaje się, że dla zachowania konstrukcyjnej symetrii i systemowej konsekwencji w stosunku do umyślnych zamachów na życie, gdy sprawca ,jednym czynem zabija więcej niż jedną osobę”, a także w imię spełnienia standardów typizacji wynikających z zasady nullum crimen sine lege certa, zasadne byłoby posłużenie się w art. $155 \S 2$ k.k. analogiczną formułą tekstową, która wprost wyrażałaby warunek jednoczynowości. Różnica między „zabijaniem” a „nieumyślnym powodowaniem śmierci” wynika bowiem jedynie z elementów strony podmiotowej, nie zaś względów przedmiotowych, które pozwalałyby na przyjęcie, że „powodowanie śmierci” może obejmować zarówno zachowania jednoczynowe, jak i wieloczynowe. „Powodowanie śmierci” to wszakże w warstwie obiektywnej takie samo zachowanie jak ,zabijanie”, a więc czyn prowadzący do „odebrania komuś życia”, przy czym realizowany bez zamiaru wywołania takiego skutku. Niezgodność między ujęciem przepisu art. $155 \S 2$ k.k. a treścią art. $148 \S 3$ in principio k.k. w praktyce wymiaru sprawiedliwości może rodzić znaczne ryzyko rozbieżności interpretacyjnych i rozchwiania linii orzeczniczej ${ }^{20}$.

Brak kompleksowego unormowania kwestii jednoczynowego zwielokrotnienia skutku objętego znamionami tego samego przepisu wyraźnie ujawnia się na płaszczyźnie aksjologicznej. Przestępstwo nieumyślnego spowodowania śmierci $\mathrm{z}$ art. $155 \S 1$ k.k. w obowiązującym stanie prawnym zagrożone jest karą od roku do 10 lat pozbawienia wolności, a w wypadku spowodowania śmierci więcej niż jednej osoby — karą od lat 2 do 15 (art. 155 § k.k.). Tymczasem za dzieciobójstwo, będące umyślnym zamachem na życie rodzącego się dziecka, niezmiennie grozi kara pozbawienia wolności od 3 miesięcy do 5 lat (art. 149 k.k.), podob-

18 Por. J. Giezek, [w:] Prawo karne materialne. Część ogólna i szczególna, red. M. Bojarski, J. Giezek, Z. Sienkiewicz, Warszawa 2017, s. 303 n.; Ł. Pohl, Prawo karne. Wyktad części ogólnej, Warszawa 2019, s. 244 n.

19 Z oczywistych powodów leżących po stronie treści podmiotowych przepisu tego nie dałoby się natomiast odnieść się do konstrukcji przestępstwa ciągłego.

20 Por. Opinia Rzecznika Praw Obywatelskich..., s. 17. 
nie jak w przypadku zabójstwa eutanatycznego (art. $150 \S 1$ k.k.), a zabójstwo w afekcie (art. $148 \S 4$ k.k.) — także bez zmian — zagrożone jest karą taką samą jak nieumyślne spowodowanie śmierci jednej osoby, znacznie łagodniejszą niż nieumyślne spowodowanie śmierci więcej niż jednej osoby. Nie można w tym miejscu nie zauważyć, że nie tylko teoretycznie możliwe są przypadki jednoczynowego dzieciobójstwa, zabójstwa eutanatycznego oraz zabójstwa w afekcie więcej niż jednej osoby. Z oczywistych względów, wynikających z zastosowania reguł wykładni systemowej, nie mogą być one podciągnięte pod jednoczynową zbrodnię zabójstwa więcej niż jednej osoby w ujęciu art. 148 § 3 in principio k.k. Dysonans między karą grożącą za nieumyślne spowodowanie śmierci więcej niż jednej osoby a karą przewidzianą za zachowania umyślne — choć podejmowane w atypowych warunkach motywacyjnych — z takim samym skutkiem, trudny jest do pogodzenia z logiką zasady ochrony życia i jej sensem.

Zmiana, jaka nastąpiła w zakresie ustawowego zagrożenia karą za nieumyślne spowodowanie śmierci człowieka z art. $155 \S 1$ k.k., oraz sankcja przewidziana za typ kwalifikowany z art. $155 \S 2$ k.k., gdy sprawca powoduje śmierć więcej niż jednej osoby, jawią się też jako rozwiązania niespójne względem zagrożeń karą przewidzianych za przestępstwa, których znamieniem kwalifikującym jest nieumyślnie wywołany skutek śmiertelny. Wprowadzone modyfikacje w zakresie penalizacji i kryminalizacji nieumyślnego spowodowania śmierci objętego regulacją rozdziału XIX kodeksu karnego nie pociągnęły bowiem za sobą zmian w ujęciu sankcji i dyspozycji innych przepisów prawnych „obocznie” chroniących życie człowieka przed nieumyślnymi zamachami wraz z innymi dobrami prawnymi, których naruszenie stało się podstawą ich usytuowania w części szczególnej ustawy karnej. Wspomnianą niekoherencję dostrzec można chociażby między regulacją art. $155 \S 1-2$ k.k. a regulacją przestępstwa spowodowania wypadku w komunikacji z art. $177 \S 2$ k.k. To ostatnie, stanowiące typ kwalifikowany wypadku ze względu na wystąpienie skutku śmiertelnego, niezmiennie zagrożone jest karą pozbawienia wolności od 6 miesięcy do 8 lat, niezależnie od liczby ofiar takiego zdarzenia, przy uwzględnieniu regulacji art. 173 k.k. Taki sam rodzaj niespójności dostrzec można między ustawowym zagrożeniem przewidzianym $\mathrm{w}$ art. 155 § 1-2 k.k. a sankcją grożącą za realizację znamion przestępstw stypizowanych w art. 163 $\S 4$ k.k., art. $165 \S 4$ k.k., a także $173 \S 4$ k.k. Przestępstwa opisane w tych przepisach pozostają zagrożone karą pozbawienia wolności od 6 miesięcy do 8 lat. Taki stan prowadzi do nierównego traktowania na gruncie prawa karnego nieumyślnych zamachów wywołujących takie same skutki ${ }^{21}$. W tym kontekście okoliczności stypizowane we wspomnianych przepisach, z których wynika skutek śmiertelny, ze względu na granice ustawowego zagrożenia karą w nich przewidziane, mogą być zatem postrzegane - wbrew wszelkim regułom racjonalnej oceny jako swoiste okoliczności uprzywilejowujące nieumyślne spowodowanie śmierci

21 Por. A. Barczak-Oplustil et al., op. cit., s. 47-48; J. Giezek et al., op. cit. 
człowieka w stosunku do regulacji art. $155 \S 1$ k.k., a zwłaszcza przestępstwa określonego w art. $155 \S 2$ k.k., w wypadkach nieumyślnego spowodowania w takich okolicznościach śmierci więcej niż jednej osoby.

\section{ORZECZENIE ŚWIADCZENIA PIENIĘŻNEGO —ART. 158 § 4 K.K.}

Omawiając konsekwencje i niekonsekwencje modyfikacji wynikających z nowelizacji kodeksu karnego z 13 czerwca 2019 roku w zakresie ochrony życia i zdrowia unormowanej przepisami rozdziału XIX kodeksu karnego, należy również zwrócić uwagę na zmianę, która objęła regulację przestępstwa udziału w bójce lub pobiciu, ściślej zaś udziału w pobiciu. Mocą nowelizacji w art. $158 \S 4$ k.k. dodana została obligatoryjna podstawa orzeczenia świadczenia pieniężnego wymienionego $\mathrm{w}$ art. 39 pkt 7 k.k. w wysokości co najmniej 5 tys. zł w razie skazania za udział w pobiciu $\mathrm{w}$ jednej z postaci określonych w $\S 1-3$ tego przepisu ${ }^{22}$. Wraz z wprowadzeniem tej zmiany wynikająca $\mathrm{z}$ art. $43 \mathrm{a}$ § $1 \mathrm{k} . \mathrm{k}$. norma upoważniająca do orzeczenia świadczenia pieniężnego „w wypadkach wskazanych w ustawie”, znajdująca dotąd w części szczególnej kodeksu karnego wyraz jedynie w art. 224b k.k., znalazła urzeczywistnienie w kolejnej podstawie jej stosowania. Na ogólnych zasadach określonych w art. 43a $\S 1$ k.k. beneficjentem tego środka jest Fundusz Pomocy Pokrzywdzonym oraz Pomocy Postpenitencjarnej. Artykuł 158 § 4 k.k. nie określa górnej granicy orzekanego świadczenia pieniężnego. W tym zakresie zastosowanie powinien zatem znaleźć art. 43a $§ 1$ k.k., wytyczający górny pułap tego środka na poziomie 60 tys. zł.

Omawiana modyfikacja, jak wprost wskazano w uzasadnieniu projektu, wynikała z potrzeby dania ,silniejszego normatywnego wyrazu temu, że pobicie cechuje się wyższym kategorialnym stopniem społecznej szkodliwości niż bójka"23. Projektodawca stanął tym samym na stanowisku — dla którego na płaszczyźnie regulacji ustawowej przestępstw stypizowanych w art. 158 i 159 k.k. trudno znaleźć stabilne wsparcie, skoro obie postacie zachowań określonych w tych przepisach, bójka i pobicie, zagrożone są tą samą sankcją — iż bójka „kategorialnie odznacza się niższym stopniem społecznej szkodliwości”. Wynika to stąd, że wszyscy jej uczestnicy „są jednocześnie atakującymi i atakowanymi, założeniem jest więc to, że pomiędzy jej uczestnikami nie powinno być formalnej dysproporcji sił"24.

22 Na marginesie należy zauważyć, że w pierwotnie uchwalonym przez Sejm brzmieniu ustawy nowelizacyjnej przepis ten obejmował jedynie sprawcę pobicia odpowiadającego na podstawie art. $158 \S 1$ k.k., co prowadziło do niezrozumiałego i nieakceptowalnego uprzywilejowania sprawców biorących udział w bardziej karygodnej formie tego przestępstwa, którego nieumyślnym skutkiem kwalifikującym był ciężki uszczerbek na zdrowiu (§ 2) lub śmierć człowieka (§ 3). Ewidentna niekonsekwencja tego rozwiązania została usunięta w fazie procedowania legislacyjnego w Senacie.

23 Uzasadnienie projektu nowelizacji kodeksu karnego..., s. 27.

24 Ibidem, s. 27-28. 
Trudno zgodzić się z taką interpretacją, zwłaszcza w kontekście tak lakonicznego jej uzasadnienia. Funkcją normy sankcjonującej wynikającej z tego przepisu jest reakcja na zdarzenia będące poważnym zagrożeniem życia lub zdrowia człowieka, niezależnie od tego, w jakiej konfiguracji, w warunkach równowagi sił czy jej braku, do wytworzenia stanu takiego narażenia doszło. Ta sama sankcja „obsługuje" wszakże obie kategorie zachowań objętych zakazem karnym — udział w bójce i udział w pobiciu. De lege lata w toku wartościowania takich zdarzeń na płaszczyźnie sądowego wymiaru kary pod uwagę należy brać jedynie ich dynamikę i skalę. Wydaje się, że wobec stanowiska zaprezentowanego w uzasadnieniu projektu lepszym zaakcentowaniem „kryminalnej odmienności” obu tych form zachowań, tradycyjnie w rodzimych kodeksach karnych typizowanych w tym samym przepisie ustawy i zagrożonych tą samą sankcją, byłoby ich odrębne ujęcie i wyposażenie w różne pod względem dolegliwości ustawowe progi odpowiedzialności karnej. Przenoszenie ocen, które mogą — choć przecież nie muszą — towarzyszyć prawnokarnej charakterystyce konkretnych zachowań realizujących znamiona bójki i pobicia w toku sądowego wymiaru kary na płaszczyznie skutków objętych ustawowym wymiarem kary i środków karnych, zwłaszcza gdy stosowanie tych środków ma charakter obligatoryjny, może budzić poważne wątpliwości.

Na tle omawianego rozwiązania kontrowersje mogą powstać także w związku ze stosowaniem świadczenia pieniężnego wobec sprawcy pobicia kwalifikowanego objętego regulacją art. 159 k.k. Wobec milczenia w tej kwestii uzasadnienia wprowadzonej zmiany trudno dociec, dlaczego ustawodawca, chcąc uwzględnić „zróżnicowanie społecznej szkodliwości bójki i pobicia”, nie uznał, że różnorodność tych zachowań powinna być uwzględniona również w przypadku typu kwalifikowanego udziału w bójce lub pobiciu człowieka określonego w art. 159 k.k., gdy sprawca pobicia, o którym mowa w art. 158 § 1-3 k.k., używa broni palnej, noża lub innego podobnie niebezpiecznego przedmiotu. Przepis art. $158 \S 4$ k.k. wprost bowiem stanowi, że sąd orzeka świadczenie pieniężne „w razie skazania za udział w pobiciu, o którym mowa w $§ 1-3$ ”. Nie ulega wątpliwości, że skazanie na podstawie art. 159 k.k. nie jest skazaniem na podstawie art. 158 § 1 k.k. Możliwość orzeczenia świadczenia pieniężnego można dopuścić jedynie w wypadku kumulatywnego zbiegu przepisów ustawy obejmującego realizację znamion art. 158 § 2-3 k.k. i art. 159 k.k. w zw. z art. $11 \S 2$ k.k. Tylko w takiej sytuacji można zasadnie przyjąć krzyżowanie się zakresów wskazanych przepisów i jednocześnie wniosek, że „skazanie” sprawcy w warunkach kwalifikacji złożonej nastąpi również na podstawie art. $158 \S 2-3$ k.k. Także zresztą wymiar kary, po nowelizacji progów ustawowego zagrożenia przewidzianego $\mathrm{w}$ art. 158 § 2-3 k.k., zgodnie $\mathrm{z}$ regułą wynikającą z art. $11 \S 3$ k.k., nastąpi na podstawie tych przepisów, sankcja art. 159 k.k. nie została bowiem objęta nowelizacją — co może być źródłem odrębnych dociekań — i w obowiązującym stanie prawnym w żadnym z powyższych wypadków krzyżowania się zakresów wspomnianych przepisów nie przewiduje „kary najsurowszej”. Wymierzenie kary według tej reguły — jak wynika z art. 11 § 3 in 
fine k.k. — nie stoi na przeszkodzie orzeczeniu innych środków przewidzianych w ustawie na podstawie wszystkich zbiegających się przepisów. Jeżeli jednak podstawą skazania sprawcy uczestniczącego w pobiciu będzie wyłącznie art. 159 k.k. — a tak będzie wówczas, gdy nie wystąpi żaden ze skutków określonych w art. $158 \S 2-3$ k.k., a sprawca pobicia używał ,broni palnej, noża lub innego podobnie niebezpiecznego przedmiotu" - nie będzie podstaw do orzeczenia przewidzianego w art. 158 § 4 k.k. świadczenia pieniężnego. Przepisy art. 159. i 158 § 1 k.k. pozostają bowiem $\mathrm{w}$ relacji zbiegu pozornego, jedyną więc podstawą skazania będzie art. 159 k.k.

Przeważający wydaje się pogląd, że art. 159 k.k. stanowi „klasyczny” typ kwalifikowany bójki lub pobicia ze względu na użyte środki w stosunku do typu podstawowego z art. $158 \S 1$ k.k. ${ }^{25}$ Relacja między art. 159 k.k. a art. 158 § 1 k.k. przypomina nieco zależność zachodzącą między przepisem art. $148 \S 2$ pkt 4 k.k. typizującym zabójstwo kwalifikowane przy użyciu materiałów wybuchowych a przepisem art. $148 \S 1$ k.k. regulującym typ podstawowy zabójstwa. W obu tych wypadkach ustawa wyodrębnia typ kwalifikowany ze względu na użyte środki, których charakter zwiększa społeczną szkodliwość zachowania sprawcy. Przy czym w pierwszej sytuacji następuje to na płaszczyźnie narażenia dobra prawnego, w drugim natomiast jego naruszenia.

Należy jednak zwrócić uwagę, że kwestia rodzaju zbiegu przepisów zachodzącego między art. $158 \S 1$ k.k. a art. 159 k.k. — pozornego czy pomijalnego — w piśmiennictwie i orzecznictwie postrzegana jest też inaczej. Odmienny pogląd wyraża między innymi A. Zoll, przyjmując, że realizacja znamion typu czynu zabronionego opisanego w art. 159 k.k. zawsze łączy się z realizacją znamion któregoś z typów określonych w art. 158 k.k. Oznaczałoby to więc, że może chodzić o każdy z nich. Jak wywodzi A. Zoll, używanie w bójce lub pobiciu broni palnej, noża lub innego podobnie niebezpiecznego przedmiotu powoduje, że „bójka lub pobicie narażają człowieka na bezpośrednie niebezpieczeństwo utraty życia albo nastąpienia skutku, o którym mowa w art. $156 \S 1$ lub art. $157 \S 1$. Przesądzona jest w tym wypadku przynajmniej kwalifikacja prawna z art. 158 § 1. Pomiędzy art. 159 i 158 § 1 zachodzi więc konsumpcja"26. Abstrahując od kwestii charakteru zbiegu, w jakim pozostają przepisy art. $158 \S 1$ k.k. i art. 159 k.k., trzeba przyjąć, że także

25 Por. W. Wolter, [w:] I. Andrejew, W. Świda, W. Wolter, Kodeks karny z komentarzem, Warszawa 1973, s. 468; T. Bojarski, Odmiany podstawowych typów przestępstw w polskim prawie karnym, Lublin 1979, s. 68; A. Spotowski, Glosa do wyroku z 25 X 1974 r., Rw 496/74, „Państwo i Prawo" 1975, nr 7-8, s. 226; J. Wojciechowski, Kodeks karny. Komentarz. Orzecznictwo, Warszawa 1998, s. 274; K. Daszkiewicz, op. cit., s. 378; A. Marek, Prawo karne, Warszawa 2011, s. 446; L. Tyszkiewicz, [w:] Kodeks karny. Komentarz, red. M. Filar, Warszawa 2010, s. 715.

26 A. Zoll, op. cit., s. 373; V. Konarska-Wrzosek, op. cit., s. 777; L. Gardocki, [w:] System Prawa Karnego, t. 4, cz. 1. O przestępstwach w szczególności, red. I. Andrejew, L. Kubicki, J. Waszczyński, Wrocław 1985, s. 459; wyrok SN z 25 października 1974 roku, sygn. Rw 496/74, OSNKW 1975, nr 1, poz. 16; wyrok SN z 30 września 1977 roku, sygn. IV KR 183/77, OSNPG 1978, nr 8-9, poz. 90; wyrok SA w Krakowie z 29 grudnia 2006 roku, sygn. II AKa 242/06, KZS 2007, nr 2, poz. 31. 
gdyby uznać, iż zbieg, o którym mowa, ma charakter zbiegu pomijalnego, nie zaś pozornego, nie będzie podstaw do orzeczenia środka przewidzianego w art. $158 \S 4$ k.k. Nie powinno bowiem budzić wątpliwości, że w żadnym z tych wypadków nie dochodzi do „skazania za udział w pobiciu, o którym mowa w art. $158 \S 1$ 1”. Poza sporem jest wszakże to, że samodzielną podstawą skazania, niezależnie od przyjętej konstrukcji zbiegu przepisów, jest art. 159 k.k., a nie art. $158 \S 1$ k.k., który traktowany jest albo jako przepis „wyłączony” (usunięty), albo „skonsumowany” (pochłonięty). W skazaniu na podstawie art. 159 k.k. nie można doszukiwać się równoczesnego skazania $\mathrm{z}$ art. $158 \S 1$ k.k. Gdyby tak było, wskazane w art. 158 $\S 4$ k.k. przepisy art. 158 § 2 i 3 k.k. także musiałyby zawierać skazanie z art. 158 § 1 k.k., odrębne przytaczanie tego przepisu byłoby więc zbyteczne. Summa summarum oznacza to, że sprawca pobicia kwalifikowanego z art. 159 k.k. znalazł się poza zakresem nakazu orzekania świadczenia pieniężnego z art. 158 § 4 k.k., wbrew tak mocno eksponowanym w uzasadnieniu jego „walorom wychowawczym”, jak i potrzebie spełniania przez ten środek zadań „W zakresie oddziaływania ogólnoprewencyjnego"27, a nade wszystko wbrew logice, celom i funkcjom tego unormowania. Odmienna interpretacja przepisu art. 158 § 4 k.k., która miałaby uzasadniać stosowanie tego środka także w razie skazania sprawcy wyłącznie z art. 159 k.k., wiązałaby się z naruszeniem reguły zakazującej stosowania analogii na niekorzyść.

\section{PODSUMOWANIE}

W kontekście zarysowanych w opracowaniu przeobrażeń unormowań dotyczących przepisów chroniących życie i zdrowie człowieka należy sformułować kilka ogólnych wniosków i ocen w kwestii ich zasadności i celowości. Deklarowanym w uzasadnieniu projektu zasadniczym celem wprowadzonych zmian było „wzmocnienie ochrony prawnokarnej w zakresie czynów godzących w tak fundamentalne dobra prawne”, a także ,zaspokojenie społecznego poczucia bezpieczeństwa i sprawiedliwości". Nie powinno budzić wątpliwości, że zmiany te nie wynikają z potrzeby reakcji ustawodawcy na zmieniającą się rzeczywistość wymagającą adekwatnych zmian unormowań prawnych. Nie ma bowiem ku temu powodów. Takiej diagnozy nie pozwalają postawić ani dane statystyczne, niewykazujące nie tylko znaczącego, ale jakiegokolwiek wzrostu liczby przestępstw tej kategorii, ani rosnące $w$ społeczeństwie obawy i poczucie zagrożenia przed przestępczością tego rodzaju $^{28}$. Z tej perspektywy jako niejasna rysuje się kwestia założonej przez ustawodawcę dysfunkcji dotychczasowych rozwiązań prawnych, która miałaby uzasad-

27 Uzasadnienie projektu nowelizacji kodeksu karnego..., s. 28.

28 Szerzej na ten temat M. Melezini, Problemy reformy prawa karnego. Uwagi na tle ustawy $z$ dn. 13 czerwca 2019 r., referat wygłoszony na Ogólnopolskiej Konferencji Naukowej „Reforma prawa karnego w latach 2015-2019”, Wrocław 21-22 listopada 2019 roku — tekst niepublikowany. 
niać wprowadzenie stosownych zmian. Wydaje się, że brak wyraźnego uzasadnienia i konsekwencji większości z nich — w tym zwłaszcza polegających na „mechanicznej" modyfikacji granic sankcji karnej - stawia pod znakiem zapytania nie tylko ich nieodzowność, lecz także racjonalnie motywowaną potrzebę ich wprowadzenia. W charakterze konkluzji należy stwierdzić, że w większości przyjęte w zakresie przepisów chroniących życie i zdrowie człowieka zmiany są wyrazem swoistego „przereagowania” ustawodawcy w sytuacji braku rzeczywistego uzasadnienia dla tak radykalnego zwiększenia surowości karania. Reakcja taka, jak wspomniano, nie znajduje oparcia ani w argumentacji kryminologicznej, ani w danych statystycznych. Wystarczającym ich uzasadnieniem nie może być w każdym razie eksponowany w uzasadnieniu projektu argument, że ciężkie przestępstwa „budzą silną społeczną potrzebę odpłaty i napiętnowania". Przestępstwa, których sankcje objęto nowelizacją, były wszakże tak samo ciężkie w chwili uchwalania kodeksu karnego z 1997 roku jak są obecnie, po upływie bez mała ćwierćwiecza jego obowiązywania. W okresie tym nie nastąpiły bowiem żadne znaczące „tąpnięcia aksjologiczne” czy statystyczne, które wymagałyby radykalnej modyfikacji jakości reakcji karnej na czyny zabronione w kierunku jej tak znacznego obostrzenia. Racjonalizowana, jak w uzasadnieniu, surowa reakcja karna może jedynie zaspokajać sprawiedliwościowo motywowaną potrzebę społecznego odwetu czy zemsty, pomija natomiast całkowicie inne, utylitarne funkcje kary kryminalnej, które limitują funkcję represyjną.

Przyjęte mocą nowelizacji kodeksu karnego z 13 czerwca 2019 roku w zakresie ochrony życia i zdrowia rozwiązania, mimo pewnych ich walorów, nie mogą zostać uznane za konieczne. Wydaje się, że reprezentują one nurt legislacyjny określany w nauce mianem „legislacji emocjonalnej”, będącej pochodną motywacji populistycznej. Pragmatyzm ustawodawcy zorientowanego nie tylko na cele prawne można łatwo wyczytać z treści uzasadnienia odwołującego się do bliżej niesprecyzowanych argumentów nawiązujących do społecznych oczekiwań, potrzeby surowszej represji, odpłaty i napiętnowania. Nie budzi wątpliwości, że taka „poetyka” i „tok narracji” charakterystyczne są, jak wskazuje się w piśmiennictwie, dla działań ustawodawcy motywowanych populizmem penalnym, dla których surowość represji karnej lub jej obietnica składana obywatelom jest efektywnym instrumentem realizacji celów pozaprawnych ${ }^{29}$. Racjonalna polityka kryminalna, która miałaby w sposób celowy kształtować rzeczywistość, musi opierać się na rzetelnych danych uzasadniających kierunek określonej reakcji prawa karnego. W omawianym zakresie ten ważki czynnik racjonalnego tworzenia prawa, jak się wydaje, umknął uwadze ustawodawcy.

${ }^{29}$ W. Wróbel, Czy powrót do racjonalizmu? Projekty nowelizacji kodeksu karnego w perspektywie zmian dokonanych w prawie karnym w latach 2005-2007, [w:] Z. Sienkiewicz, R. Kokot, Populizm penalny i jego przejawy w Polsce, Wrocław 2009, s. 107. 


\title{
SOME CONSEQUENCES AND INCONSISTENCIES OF CHANGES IN THE PROTECTION OF LIFE AND HEALTH IN THE AMENDMENT TO THE PENAL CODE OF JUNE 13, 2019
}

\begin{abstract}
Summary
The article attempts to present the most important changes that have occurred in the provisions protecting human life and health along with the adoption on June 13, 2019 of an amendment to the Penal Code. Their dual nature is noteworthy. On the one hand, the modifications are aimed at restricting the level of criminal liability for some crimes in chapter XIX of the Criminal Code, including for more severe forms of homicide, causing damage to health, inadvertently causing death, or participating in a fight or beating. On the other hand, the amendment introduces new types of crimes, also unknown to earlier codifications of domestic criminal law, such as accepting a contract murder or causing the death of more than one person, as well as a different formula of responsibility for preparing and planning a murder. Considering the scope of these changes, the discussed amendment should be considered as the deepest interference with the legal status in the area of protection of the unit's basic goods under the 1997 Criminal Code. The study presents the assumptions of some of the adopted solutions, analysis of the legitimacy of their introduction, and assessment of their systemic consistency, and an analysis of the consequences that these changes may entail in terms of increasing the effectiveness of preventing and combating crime directed against human life and health.
\end{abstract}

Keywords: amendment, life, health, inadvertently causing death, fight, beating, punishment, penalization, criminalization, rationality, repression

\section{BIBLIOGRAFIA}

\section{LITERATURA}

Andrejew I., Świda W., Wolter W., Kodeks karny z komentarzem, Warszawa 1973.

Bojarski T., Odmiany podstawowych typów przestępstw w polskim prawie karnym, Lublin 1979.

Daszkiewicz K., Przestęstwa przeciwko życiu i zdrowiu. Rozdziat XIX Kodeksu karnego. Komentarz, Warszawa 2000.

Kodeks karny. Część szczególna. Komentarz, t. 2, red. A. Zoll, Kraków 2006.

Kodeks karny. Komentarz, red. M. Filar, Warszawa 2010.

Kodeks karny. Komentarz, red. A. Grześkowiak, K. Wiak, Warszawa 2018.

Kodeks karny. Komentarz, red. V. Konarska-Wrzosek, Warszawa 2016.

Kodeks karny. Komentarz, red. R.A. Stefański, Warszawa 2018.

Kokot R., Penalizacja przygotowania zabójstwa w nowelizacji kodeksu karnego z 13 czerwca 2019 roku, , Przegląd Prawa i Administracji” 120, 2020.

Kokot R., Przestępstwo przyjęcia zlecenia zabójstwa (art. 148 a 11 k.k.) w ujęciu nowelizacji kodeksu karnego z 13 czerwca 2019 roku, „, Przegląd Prawa i Administracji” 122, 2020.

Marek A., Prawo karne, Warszawa 2011.

Melezini M., Problemy reformy prawa karnego. Uwagi na tle ustawy z dn. 13 czerwca 2019 roku, referat wygłoszony na Ogólnopolskiej Konferencji Naukowej „Reforma prawa karnego w latach 2015-2019", Wrocław 21-22 listopada 2019 roku — tekst niepublikowany.

Pohl Ł., Prawo karne. Wykład części ogólnej, Warszawa 2019. 
Prawo karne materialne. Część ogólna i szczególna, red. M. Bojarski, J. Giezek, Z. Sienkiewicz, Warszawa 2017.

Sienkiewicz Z., Kokot R., Populizm penalny i jego przejawy w Polsce, Wrocław 2009.

Spotowski A., Glosa do wyroku z 25 X 1974 r., Rw 496/74, „Państwo i Prawo” 1975, nr 7-8.

System Prawa Karnego, t. 4, cz. 1. O przestępstwach w szczególności, red. I. Andrejew, L. Kubicki, J. Waszczyński, Wrocław 1985.

U progu nowych kodyfikacji karnych. Księga pamiatkowa ofiarowana Prof. Leonowi Tyszkiewiczowi, red. O. Górniok, Katowice 1999.

Wojciechowski J., Kodeks karny. Komentarz. Orzecznictwo, Warszawa 1998.

\section{ORZECZNICTWO}

Postanowienie SN z 30 października 2008 roku, sygn. I KZP 13/08, OSNKW 2008, nr 11, poz. 90. Uchwała SN z 26 października 2006 roku, sygn. I KZP 18/06, OSNKW 2006, nr 11, poz. 97. Wyrok SA w Krakowie z 29 grudnia 2006 roku, sygn. II AKa 242/06, KZS 2007, nr 2, poz. 31. Wyrok SN z 25 października 1974 roku, sygn. Rw 496/74, OSNKW 1975, nr 1, poz. 16. Wyrok SN z 30 września 1977 roku, sygn. IV KR 183/77, OSNPG 1978, nr 8-9, poz. 90. Wyrok SN z 27 września 2010 roku, sygn. V KK 34/10, OSNKW 2010, nr 12, poz. 105.

\section{ŹRÓDŁA INTERNETOWE}

Barczak-Oplustil A., Górowski W., Małecki M., Zontek W., Tarapaty S., Wróbel W., Iwański M., Opinia do uchwały Senatu Rzeczypospolitej Polskiej z dnia 24 maja 2019 roku w sprawie ustawy o zmianie ustawy - Kodeks karny oraz niektórych innych ustaw, uchwalonej przez Sejm Rzeczypospolitej Polskiej na 81. posiedzeniu w dniu 16 maja 2019 roku, Kraków, dnia 9 czerwca 2019 roku, https://www.rpo.gov.pl/sites/default/files/Opinia\%20Krakowskiego\%20 Instytutu\%20Prawa\%20Karnego\%20Fundacja\%20ws.\%20poprawek\%20Senatu\%209\%20 czerwca\%202019.pdf.

Gardocka T., Opinia dotycząca ustawy zmieniającej kodeks karny i niektóre inne ustawy, uchwalonej przez Sejm dnia 16 maja 2019 roku i skierowanej do Senatu, sporządzona dnia 22 maja 2019 roku na prośbę Rzecznika Praw Obywatelskich, https://www.rpo.gov.pl/sites/default/files/Opinia\%20dr\%20hab.\%20Teresy\%20Gardockiej\%20ws\%20zmian\%20w\%20prawie\%20 karnym $\% 2$ C $\% 2022 \% 20$ maja\%202019.pdf.

Giezek J., Brzezińska J., Gruszecka D., Kokot R., Lipiński K., Opinia na temat projektu zmian przepisów kodeksu karnego (uchwała Senatu Rzeczypospolitej Polskiej z dnia 24 maja 2019 roku), Wrocław 2019,https://www.rpo.gov.pl/sites/default/files/Opinia Katedry Prawa Karnego Materialnego WPAE UWr do nowelizacji kodeksu karnego.pdf.

Opinia o nowelizacji KK 158 prawników ze wszystkich ośrodków naukowych, 23 czerwca 2019 roku, https://www.rpo.gov.pl/sites/default/files/Opinia\%20\%20o\%20nowelizacji\%20 Kk\%20158\%20prawnik\%C3\%B3w\%20ze\%20\%20wszystkich\%20\%20o\%C5\%9Brodk\%C3\%B3w\%20naukowych\%2C\%2023\%20czerwca\%202019.pdf.

Opinia Rzecznika Praw Obywatelskich do ustawy z dnia 16 maja 2019 roku o zmianie ustawy — Kodeks karny oraz niektórych innych ustaw, Warszawa, 20 maja 2019 roku, https://www. rpo.gov.pl/sites/default/files/Opinia\%20RPO $\% 20$ dla\%20Senatu $\% 20 \mathrm{ws} \% 20 \mathrm{zmian} \% 20 \mathrm{w} \% 20$ prawie\%20karnym\%2C\%2020\%20maja\%202019.pdf.

Sakowicz A., Stanowisko dla Rzecznika Praw Obywatelskich w związku z uchwalaniem przez Sejm RP ustawy z dnia 16 maja 2019 roku o zmianie ustawy — Kodeks karny oraz niektó- 
rych innych ustaw, Białystok, 21 maja 2019 roku, https://www.rpo.gov.pl/sites/default/files/ Opinia\%20dr.\%20hab.\%20Andrzeja\%20Sakowicza\%20ws\%20zmian\%20w\%20prawie $\% 20$ karnym\%2C\%2021\%20maja\%202019.pdf.

Sąd Najwyższy Rzeczypospolitej Polskiej, Biuro Studiów i Analiz, Opinia do projektu ustawy o zmianie ustawy — Kodeks karny oraz niektórych innych ustaw, Warszawa, 26 kwietnia 2019, https://www.rpo.gov.pl/sites/default/files/Uwagi\%20S\%C4\%85du\%20Najwy $\%$ C5\%BCszego\%20do\%20projektu\%20zmian\%20prawa\%20karnego\%2026\%20kwietnia\%202019.pdf.

Uzasadnienie projektu nowelizacji kodeksu karnego — wersja z 5 kwietnia 2019 roku, https://legislacja.rcl.gov.pl. 